A ten-year literature review of content-based image retrieval (CBIR) studies in the tourism industry

\begin{tabular}{|r|l|}
\hline Journal: & The Electronic Library \\
\hline Manuscript ID & EL-06-2020-0149.R2 \\
\hline Manuscript Type: & Article \\
\hline Keywords: & Content-based image retrieval, Digital image indexing, Tourism \\
\hline
\end{tabular}

SCHOLARONE
Manuscripts 


\title{
A ten-year literature review of content-based image retrieval (CBIR) studies in the tourism industry
}

\begin{abstract}
Purpose - Due to the worldwide growth of digital image sharing and the maturity of the tourism industry, the vast and growing collections of digital images have become a challenge for those who use and/or manage these image data across tourism settings. To overcome the image indexing task with less labour cost and improve the image retrieval task with less human errors, the content-based image retrieval (CBIR) technique has been investigated for the tourism domain particularly. This paper aims to review the relevant literature in the field to understand these previous works and identify research gaps for future research directions.
\end{abstract}

Design/methodology/approach - The systematic and comprehensive review of CBIR studies in tourism from the year 2010 to 2019, focusing on journal articles and conference proceedings in reputable online databases, is conducted by taking a comparative approach to critically analyse and address the trend of each fundamental element in these research experiments.

Findings - Based on the review of the literature, the trends identified in the CBIR study in tourism is to improve image representation and retrieval by advancing existing feature extraction techniques, contributing novel techniques in the feature extraction process through fine-tuning fusion features, and improving image query of CBIR systems. Co-authorship, tourist attraction sector, and fusion image features have been a focus. Nonetheless, the number of studies in other tourism sectors and available image databases could be further explored.

Originality/value - The fact that no existing academic review of CBIR studies in tourism makes this paper a novel contribution.

Keywords: Content-based image retrieval, Digital image indexing, Tourism industry Article classification: Literature review

\section{Introduction}

The tourism industry has been one of the driving forces of the economy for many countries around the world (WTTC, 2020). In 2019, the industry contributed US $\$ 8.9$ trillion to the world's GDP, accounting for 10.3 percent of global GDP, and provided 330 million jobs - one in ten jobs - around the world. Moreover, US $\$ 948$ billion capital investment was allocated to the industry. Additionally, despite the service nature of tourism, it can be seen as a tourism product which consists of five elements including: attractions, access, accommodation, amenities, and activities (Mill and Morrison, 1985; Murphy et al., 2000; Smith, 1994).

Looking at today's society, it is undeniable that social media have become major portals for digital image sharing. As a result of our love of taking pictures when travelling internationally or domestically and taking pictures or screenshots of moments in our daily lives, 350 million images are uploaded every day on Facebook, more than 50 billion images so far have been uploaded to Instagram, over 1.2 billion images and videos are uploaded on Google Photos, and Flickr, the largest image sharing website, hosts more than 500 million public CC-licensed images (Aslam, 2020a, 2020b; Sabharwal, 2017; Stadlen, 2019). On top of this, due to the popularity of smartphones equipped with cameras, over 98 percent of Facebook active user accounts have accessed the social network via smartphone (Clement, 2020) which confirms the convenient production and sharing of digital images. Apart from image sharing, six out of ten Pinterest users also use the mobile app to discover new products and 83 percent of them use mobile search in the decision making process of purchases (Aslam, 2020c).

Consequently, this continuous production of digital images, especially in a tourism-related context, has become a challenge in image data organization not only for public users who try to organize their own personal catalogue or search for images in any database, but also professional groups, such as librarians, tourism authorities, museum managers, online travel agencies, social media companies, and search engine companies who try to electronically manage and index these vast collections for image retrieval purposes. Digital images contain high-dimensional data which 
contribute a greater challenge in various aspects of its management and organization, such as huge memory and storage requirements, high computational costs, speed limitations, and security constraints. Furthermore, the complex digitization process, indexing process, and the need for efficient storage and retrieval of images have been recognized for many years among professionals who manage picture libraries and design archives in large image collections. Nonetheless, to overcome these challenges, academic scholars and commercial research groups have studied and advanced numerous techniques in response to image classification and retrieval. Alkhawlani et al. (2015) mentioned three key image retrieval techniques which are text-based image retrieval (TBIR), semantic-based image retrieval (SBIR), and content-based image retrieval (CBIR). To reduce intensive labour cost and human errors in image data indexing and retrieval, as well as complement the digital image era, CBIR seems to be the ideal solution for image data management.

Despite the fact that digital images have also been produced heavily in other domains, such as radiology in medicine and the plant/animal kingdom in biology, this research focuses on the tourism domain, based on its economic impact aforementioned. Consequently, this paper will conduct a systematic and comprehensive review of CBIR studies in the tourism industry in the past ten years, the year 2010 to the year 2019. The rest of this paper is organized as follows. Section 2 illustrates the concept of CBIR including image representation and measurements of retrieval performance. Section 3 investigates the relevant literature of CBIR in tourism with critical analysis. Lastly, future research directions are discussed in Section 4 and Section 5 provides the conclusion, accordingly.

\section{CBIR theory}

First of all, it is crucial to understand the process of CBIR. As shown in Figure 1, each image in the database is automatically extracted and its features and mathematics measured. Once a user submits an image query, the system will compare the features of the submitted image to features of images extracted prior to it in the database in order to match and present the image(s) that look most similar.

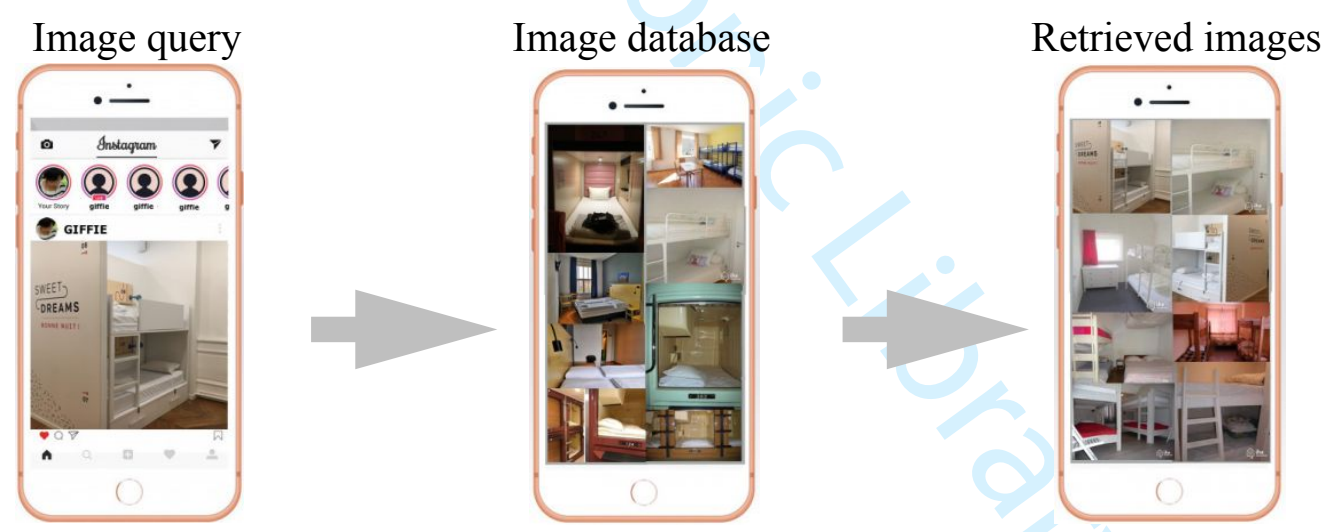

Figure 1. The process of content-based image retrieval (CBIR)

In addition, an image query could be in the forms of sketch or colour map, however, using an image example would be the most appropriate image type for CBIR as it has well-represented attributes of an image, such as the presence of a particular combination of colour, shape, and/or texture, the presence or arrangement of the object(s) in an image, and the presence of location(s), event(s), or individual(s). It can be seen that the content-based technique could be a more challenging one compared to the semantic-based or the text-based techniques which use words as tools of communication and are logically structured by a human (Santini and Jain, 1997). However, by using the CBIR technique the closest image(s) would be retrieved with less human errors in image indexing and organization.

Moving to the image representation, through the feature extraction process, an image could be represented in the form of image features. These features could be broadly categorized into two types of features, classical features and artificial intelligence-based features. 
Traditionally, image features can be represented in colours, textures, shapes, spatial positions, or in the form of scale-invariant feature transform (SIFT) as described below.

A. Colour features - Colour has been one of the most studied features as it is a vital element when it comes to human visual perception. Despite the fact that there are various colour systems, RGB (red, green, and blue) is the most widely mentioned and used colour system even though it is not the most corresponding colour system to a human's colour perception (Muller et al., 2003).

B. Texture features - Similar to the colour feature, human visual perception tends to consider textures of objects in an image. For example, a fur texture of a hotel cushion, a wood texture of the pier floor, a leather texture of a car seat, or metal texture of a sculpture.

C. Shape features - Another classical feature used in CBIR is the shape feature. Each object in an image may differ in shape, such as a rectangular shape of a hostel bed, a square shape of a window, a circle shape of a soup bowl, or a triangle shape of the Eiffel Tower.

D. Spatial features - The spatial position of an object within an image is one of the most basic and sensible features for image search as a geographical aspect can be seen in a real-life example. This useful feature helps to make the process of image search more accurate. However, image rotation is a challenge for this type of feature.

E. Scale-invariant feature transform (SIFT) features - The scale-invariant feature transform (SIFT) feature, which is also considered a classical or handcrafted feature (Zhou et al., 2017), introduced by Lowe in 2004, has been studied in numerous works as it focuses on the key point(s) of interest in an image and this key point is invariant to scale, rotation, location, and illumination, unlike the spatial features. Based on this key strength of the SIFT feature, it could contribute to better accuracy of an image search in vast image libraries.

Nowadays it can be seen that artificial intelligence (AI) has become one of the most discussed topics as several tasks previously operated by only human beings have now transferred to computing machines which can run automatically. As AI is a powerful tool, artificial neural networks (ANNs) have been explored in feature extraction in order to simulate the human cognition process. Firstly, the image attribute(s) are manually defined by a human. Then, the designed system can be trained to recognize the labelled image and this learning-based feature can be used to compare to visual feature(s) of an unseen image(s) for the purpose of retrieving similar image(s). Among various types of ANNs, the convolutional neural network (CNN) has been primarily applied on several image recognition and retrieval works including, for example, AlexNet, ZF Net, VGG Net, and GoogLeNet (Adit, 2016; Kruthika et al., 2019; Tzelepi and Tefas, 2017). Nonetheless, the extraction of these AIbased features remains a challenge as it is not easy to define all attributes or features for an image, due to the complexity of the human neural network that the ANN should be able to simulate, and also the image classification process is quite time and cost consuming.

\subsection{Performance measurement of CBIR}

The evaluation of a CBIR system is crucial as it is the tool to measure the image retrieval performance in terms of its successfulness in practical application. Despite a variety of performance evaluation criterion, two widely used measures in CBIR and information retrieval are precision and recall.

Precision is a ratio of the number of relevant retrieved images to the total number of retrieved images.

$$
\text { Precision }=\frac{\text { No. of relevant retrieved images }}{\text { No. of relevant }+ \text { irrelevant retrieved images }} \quad \text { (Equation 1) }
$$

Recall is a ration of the number of relevant retrieved images to the total number of relevant images in the database.

$$
\text { Recall }=\frac{\text { No. of relevant retrieved images }}{\text { No. of relevant images in database }} \quad \text { (Equation 2) }
$$

\section{Literature review}

\subsection{Research methodology}

Due to the nature of the literature review, secondary research is chosen as a methodology in order to collect published materials which are in relation to CBIR studies in the tourism industry. Additionally, 
prior to conducting the critical analysis of relevant literature, a systematic and comprehensive approach is adopted in the literature review process. Brunel University London (2020) suggested five stages of a literature review process which are to: identify a well-defined literature review question, develop a searching strategy, evaluate the identified literature, combine the relevant literature, and reiterate the purpose of the review.

To begin with, the stage of identifying a literature review question is a very critical stage. A well-defined literature review question helps a researcher to be more focused and includes only relevant literature that will help to answer the literature review question. Furthermore, after identifying the question, demonstrating the terms used in the literature search is also unneglectable as clearly defined terms help to reduce any ambiguity that may occur in later stages. Therefore, for the purpose of answering the review question of this study, what the evidence of CBIR studies are in the tourism industry, two key terms were identified, CBIR and tourism.

Moving to the stage of developing a searching strategy, a strategic and systematic approach could greatly benefit as a researcher will remain focused on answering the literature review question. Despite there being a large number of literature available for researchers, such as books, academic or professional journals, conference papers, and newspapers, each type of literature has a specific audience of intended readers for which the articles have been written, as well as the styles of writing may vary. More importantly, reliability is also a key consideration. Therefore, it is crucial to prioritise the types of literature and develop a hierarchy of evidence in order to focus on the literature sources that produce high-quality literature. Consequently, in the case of this study, a search of research literature was conducted from online databases with a high reputation in academic use, including Brunel University Library, IEEE/IET Electronic Library, Academic Search Complete, ACM Digital Library, and Google Scholar, in order to gather relevant studies with a focus on journal articles and conference proceedings. Additionally, the publication year for the literature search was set from the year 2010 and up to the year 2020 .

Despite the fact that the majority of identified literature was from peer reviewed journals, literature evaluation could reassure that the literature was able to contribute useful evidence to the literature review. Therefore, an appraisal tool from a critical appraisal skills programme (CASP, 2020) was adopted in order to critically examine each piece of literature by considering three broad issues: the validity of the results of the study, the contents of the results, and the benefits of the results.

Looking at the next stage of a literature review process which is the stage of combining the relevant literature, it is undoubted that not only evaluating each piece of literature is important but also drawing similarity(s) and difference(s) of all the literature is crucial. For this reason, the common ground(s) and the distinction(s) of retrieved literature are addressed in the section of results and analysis.

Despite the fact that the literature review purpose can be implied from the literature review question in the stage of identifying a literature review question, it is essential to emphasise the review purpose(s) as well as signpost any activities that could be undertaken further. Therefore, the sections of future research directions and conclusion are included.

\subsection{Results and analysis}

After the search of previous CBIR studies in the tourism industry in the past decade, a comparative study of key elements and results from each experiment are highlighted in Table I with critical analysis.

Table I. The comparative study of CBIR in the tourism discipline

\begin{tabular}{|l|l|l|l|l|l|l|}
\hline Author(s) & $\begin{array}{l}\text { Country(s) \& } \\
\text { publication }\end{array}$ & $\begin{array}{l}\text { Image } \\
\text { database(s) } \\
\text { \& format(s) }\end{array}$ & $\begin{array}{l}\text { No. of } \\
\text { images \& } \\
\text { classes }\end{array}$ & $\begin{array}{l}\text { Extracted } \\
\text { feature(s) }\end{array}$ & $\begin{array}{l}\text { Performance } \\
\text { measurement(s) } \\
\text { \& result(s) }\end{array}$ & $\begin{array}{l}\text { Summary of } \\
\text { findings }\end{array}$ \\
\hline
\end{tabular}




\begin{tabular}{|c|c|c|c|c|c|c|}
\hline $\begin{array}{l}\text { Premchai } \\
\text { swad et } \\
\text { al. (2010) }\end{array}$ & $\begin{array}{l}\text { Thailand } \\
\text { (IEEE) }\end{array}$ & $\begin{array}{l}\text { Tourist } \\
\text { attractions } \\
\text { (JPEG, } \\
\text { BMP \& } \\
\text { GIF) }\end{array}$ & $3,600(\mathrm{n} / \mathrm{a})$ & $\begin{array}{l}\text { colour } \\
\text { correlogra } \\
\mathrm{m}\end{array}$ & $\begin{array}{l}\text { Precision }(89 \%), \\
\text { recall }(227) \text {, mean } \\
\text { average precision } \\
(86 \%) \& \text { mean } \\
\text { average recall }(2)\end{array}$ & $\begin{array}{l}\text { The ACCC } \\
\text { (auto colour } \\
\text { correlogram } \\
\text { and } \\
\text { correlation) } \\
\text { algorithm } \\
\text { outperforms } \\
\text { the ACC } \\
\text { (auto colour } \\
\text { correlogram } \\
\text { ) algorithm } \\
\text { for CBIR }\end{array}$ \\
\hline $\begin{array}{l}\text { Wengert } \\
\text { et al. } \\
(2011)\end{array}$ & $\begin{array}{l}\text { Switzerland \& } \\
\text { France } \\
\text { (Proceedings of } \\
\text { the 19th ACM } \\
\text { International } \\
\text { Conference on } \\
\text { Multimedia) }\end{array}$ & $\begin{array}{l}\text { INRIA } \\
\text { holidays } \\
\text { (JPEG) }\end{array}$ & $1,491(500)$ & $\begin{array}{l}\text { colour } \quad \& \\
\text { SIFT }\end{array}$ & $\begin{array}{l}\text { Mean average } \\
\text { precision }(65.3 \%)\end{array}$ & $\begin{array}{l}\text { The colour } \\
\text { SIFT } \\
\text { descriptor } \\
\text { outperforms } \\
\text { the SIFT } \\
\text { descriptor } \\
\text { for CBIR }\end{array}$ \\
\hline $\begin{array}{l}\text { Raisi et } \\
\text { al. }(2011)\end{array}$ & Iran (IEEE) & $\begin{array}{l}\text { own } \\
\text { tourism } \\
\text { database } \\
\text { (attractions } \\
\text { of Zahedan } \\
\text { city and } \\
\text { University } \\
\text { of Sistan } \\
\text { and } \\
\text { Baluchestan } \\
\text { (n/a) }\end{array}$ & $1,021(\mathrm{n} / \mathrm{a})$ & $\begin{array}{l}\text { colour, } \\
\text { texture, \& } \\
\text { edge }\end{array}$ & $\begin{array}{l}\text { Average } \\
\text { normalized } \\
\text { modified retrieval } \\
\text { rate }(0.3444 \text { for } \\
\text { EHD } \& \text { running } \\
\text { time }(0.06 \mathrm{~s} \text { for } \\
\text { SCD })\end{array}$ & $\begin{array}{l}\text { The EHD } \\
\text { (edge } \\
\text { histogram } \\
\text { descriptor) } \\
\text { and the SCD } \\
\text { (scale } \\
\text { colour } \\
\text { descriptor) } \\
\text { methods } \\
\text { outperform } \\
\text { the others } \\
\text { for CBIR }\end{array}$ \\
\hline $\begin{array}{l}\text { Abdullah } \\
\text { zadeh and } \\
\text { Mohanna } \\
(2013)\end{array}$ & \begin{tabular}{|l} 
Iran \\
(International \\
Research \\
Journal of \\
Applied and \\
Basic Sciences)
\end{tabular} & $\begin{array}{l}\text { Building } \\
\text { category of } \\
\text { Corel } \\
\text { (JPEG) }\end{array}$ & $100(\mathrm{n} / \mathrm{a})$ & colour & $\begin{array}{l}\text { Average } \\
\text { normalized } \\
\text { modified retrieval } \\
\text { rate }(0.0759)\end{array}$ & $\begin{array}{l}\text { The } \\
\text { combined } \\
\text { gray and } \\
\text { HSV colour } \\
\text { ANIRs } \\
\text { (affine noisy } \\
\text { invariant } \\
\text { region) } \\
\text { algorithm } \\
\text { outperforms } \\
\text { the others } \\
\text { for CBIR }\end{array}$ \\
\hline
\end{tabular}




\begin{tabular}{|c|c|c|c|c|c|c|}
\hline $\begin{array}{lr}\text { Raisi } & \text { et } \\
\text { al. }(2014)\end{array}$ & \begin{tabular}{|l|} 
Iran \\
(International \\
Journal of \\
Advanced \\
Networking \\
and \\
Applications)
\end{tabular} & $\begin{array}{l}\text { own } \\
\text { tourism } \\
\text { database } \\
\text { (attractions } \\
\text { of Zahedan } \\
\text { city and } \\
\text { University } \\
\text { of Sistan } \\
\text { and } \\
\text { Baluchestan } \\
\text { ) \& } \\
\text { Corel_1k } \\
\text { (n/a) }\end{array}$ & $\mid \begin{array}{lr}1,000 & (17) \\
\& & 1,000 \\
(20) & \end{array}$ & $\begin{array}{l}\text { colour, } \\
\text { texture, \& } \\
\text { shape }\end{array}$ & $\begin{array}{l}\text { average } \\
\text { normalized } \\
\text { modified retrieval } \\
\text { rate }(0.2751 \text { for } \\
\text { EHD \& CLD) \& } \\
\text { query running } \\
\text { time (0.050s for } \\
\text { SCD) }\end{array}$ & $\begin{array}{l}\text { The } \\
\text { combined } \\
\text { EHD (edge } \\
\text { histogram } \\
\text { descriptor) } \\
\text { with CLD } \\
\text { (colour } \\
\text { layout } \\
\text { descriptor) } \\
\text { and the SCD } \\
\text { (scale } \\
\text { colour } \\
\text { descriptor) } \\
\text { methods } \\
\text { outperform } \\
\text { the others } \\
\text { for CBIR }\end{array}$ \\
\hline $\begin{array}{l}\text { Zheng et } \\
\text { al. (2014) }\end{array}$ & $\begin{array}{l}\text { China (IEEE } \\
\text { Transactions } \\
\text { on Image } \\
\text { Processing) }\end{array}$ & $\begin{array}{l}\text { INRIA } \\
\text { holidays, } \\
\text { Ukbench,D } \\
\text { uImage \& } \\
\text { MIR Flickr } \\
\text { 1M (JPEG) }\end{array}$ & $\begin{array}{l}1,491(500) \\
10,200 \\
(2,250) \\
1,104(33) \\
\& 1 \mathrm{M}(\mathrm{n} / \mathrm{a})\end{array}$ & $\begin{array}{l}\text { colour \& } \\
\text { SIFT }\end{array}$ & $\begin{array}{l}\text { Mean } \\
\text { precision } \\
(85.2 \%)\end{array}$ & $\begin{array}{l}\text { The } \\
\text { combined } \\
\text { SIFT \& } \\
\text { colour } \\
\text { algorithm } \\
\text { outperforms } \\
\text { the others } \\
\text { for CBIR }\end{array}$ \\
\hline $\begin{array}{l}\text { Zhu et al. } \\
(2015)\end{array}$ & $\begin{array}{l}\text { China (IEEE } \\
\text { Transactions } \\
\text { on Cybernetics) }\end{array}$ & $\begin{array}{l}\text { Landmarks } \\
\text { from Flickr } \\
(\mathrm{n} / \mathrm{a})\end{array}$ & $5,000(25)$ & $\begin{array}{l}\text { colour } \\
\text { moment, } \\
\text { texture, } \\
\text { shape, } \\
\text { SIFT, \& } \\
\text { GIST }\end{array}$ & $\begin{array}{l}\text { Precision } \\
(29.77 \%)\end{array}$ & $\begin{array}{l}\text { The MMHG } \\
\text { (multimodal } \\
\text { hypergraph) } \\
\text { algorithm } \\
\text { outperforms } \\
\text { the others } \\
\text { for CBIR }\end{array}$ \\
\hline $\begin{array}{l}\text { Amato et } \\
\text { al. (2015) }\end{array}$ & \begin{tabular}{|lr} 
Italy & $(A C M$ \\
Journal & on \\
Computing & and \\
Cultural & \\
Heritage $)$ &
\end{tabular} & $\begin{array}{l}\text { Pisa } \\
\text { monuments } \\
\& \\
\text { landmarks } \\
\text { from Flickr } \\
(\mathrm{n} / \mathrm{a})\end{array}$ & $1,227(12)$ & $\begin{array}{|ll|}\text { SIFT, } & \\
\text { SURF, } & \\
\text { ORB } \quad \& \\
\text { BRISK }\end{array}$ & F1 macro $(0.95)$ & $\begin{array}{l}\text { The kNN (k- } \\
\text { nearest } \\
\text { neighbour) } \\
\text { with SIFT } \\
\text { algorithm } \\
\text { outperforms } \\
\text { the others } \\
\text { for CBIR }\end{array}$ \\
\hline$\left|\begin{array}{l}\text { Wang } \\
\text { al. }(2015)\end{array}\right|$ & $\begin{array}{l}\text { Australia } \\
\text { (Proceedings of } \\
\text { the 23rd ACM } \\
\text { International } \\
\text { Conference on } \\
\text { Multimedia) }\end{array}$ & $\begin{array}{l}\text { Landmarks } \\
\text { from Flickr, } \\
\text { Picasa web } \\
\text { album \& } \\
\text { Oxford } \\
\text { building } \\
\text { (n/a) }\end{array}$ & $\left|\begin{array}{lr}49,840 & (55) \\
4,100 & (16) \\
\& & 5,062 \\
(12) & \end{array}\right|$ & $\begin{array}{ll}\text { shape } \quad \& \\
\text { SIFT }\end{array}$ & $\begin{array}{l}\text { Mean average } \\
\text { precision } \\
(59.94 \%)\end{array}$ & $\begin{array}{l}\text { The novel } \\
\text { method base } \\
\text { on a multi- } \\
\text { query } \\
\text { expansion } \\
\text { paradigm } \\
\text { outperforms } \\
\text { the others } \\
\text { for CBIR }\end{array}$ \\
\hline
\end{tabular}




\begin{tabular}{|c|c|c|c|c|c|c|}
\hline $\begin{array}{l}\text { Makantas } \\
\text { is et al. } \\
(2016)\end{array}$ & $\begin{array}{l}\text { Greece } \quad \& \\
\text { Cyprus } \\
\text { (Multimedia } \\
\text { Tools and } \\
\text { Applications) }\end{array}$ & $\begin{array}{l}\text { Cultural } \\
\text { heritage } \\
\text { from Flickr } \\
(\mathrm{n} / \mathrm{a})\end{array}$ & $31,000(\mathrm{n} / \mathrm{a})$ & ORB & $\begin{array}{l}\text { Precision }(78 \%), \\
\text { recall }(92 \%) \& \mathrm{~F} 1 \\
\text { Score }(84 \%)\end{array}$ & $\begin{array}{l}\text { The } \\
\text { DBSCAN } \\
\text { (density- } \\
\text { based } \\
\text { spatial } \\
\text { clustering of } \\
\text { applications } \\
\text { with noise) } \\
\text { algorithm } \\
\text { outperforms } \\
\text { the others } \\
\text { for CBIR }\end{array}$ \\
\hline $\begin{array}{l}\text { Lacheheb } \\
\text { and Aouat } \\
(2017)\end{array}$ & $\begin{array}{l}\text { Algeria } \\
\text { (Multimedia } \\
\text { Tools and } \\
\text { Applications) }\end{array}$ & $\begin{array}{l}\begin{array}{l}\mathrm{ZuBuD} \\
\text { (PNG), } \\
\text { WANG \& } \\
\text { Coil-100 } \\
(\mathrm{n} / \mathrm{a})\end{array}\end{array}$ & \begin{tabular}{|lr}
1,120 & $(201)$ \\
1,000 & $(10)$ \\
$\&$ & 7,200 \\
$(\mathrm{n} / \mathrm{a})$ &
\end{tabular} & \begin{tabular}{|l} 
colour \& \\
SIFT
\end{tabular} & $\begin{array}{l}\text { Precision }(56 \%), \\
\text { recall }(100 \%), F- \\
\text { measure }(70 \%) \& \\
\text { error rate }(0.01)\end{array}$ & $\begin{array}{l}\text { The } \\
\text { combined } \\
\text { SIFT \& } \\
\text { HSV } \\
\text { algorithm } \\
\text { outperforms } \\
\text { the others } \\
\text { for CBIR }\end{array}$ \\
\hline $\begin{array}{l}\text { Elleuch } \\
\text { and } \\
\text { Marzouki } \\
(2017)\end{array}$ & $\begin{array}{l}\text { Tunisia } \\
\text { (Multimedia } \\
\text { Tools and } \\
\text { Applications) }\end{array}$ & $\begin{array}{l}\text { INRIA } \\
\text { holidays } \\
\text { (JPEG), } \\
\text { Ukbench, } \\
\text { MIR Flickr } \\
1 \mathrm{M} \& \text { Flickr } \\
60 \mathrm{~K}(\mathrm{n} / \mathrm{a})\end{array}$ & $\begin{array}{l}1,491(500) \\
10,200 \\
(2,250), \\
(\mathrm{n} / \mathrm{a}) \quad \& \\
67,714(\mathrm{n} / \mathrm{a})\end{array}$ & $\begin{array}{l}\text { colour } \quad \& \\
\text { SIFT }\end{array}$ & $\begin{array}{l}\text { Mean average } \\
\text { precision }(59.4 \%)\end{array}$ & $\begin{array}{l}\text { The novel } \\
\text { multi-IDF } \\
\text { (inverse } \\
\text { document } \\
\text { frequency) } \\
\text { design } \\
\text { algorithm } \\
\text { outperforms } \\
\text { the others } \\
\text { for CBIR }\end{array}$ \\
\hline $\begin{array}{l}\text { Lonarkar } \\
\text { and Rao } \\
(2017)\end{array}$ & $\begin{array}{l}\text { India } \\
\text { (Proceedings of } \\
\text { the } \\
\text { International } \\
\text { Conference on } \\
\text { Inventive } \\
\text { Computing and } \\
\text { Informatics) }\end{array}$ & $\begin{array}{l}\text { INRIA } \\
\text { holidays } \\
\text { (JPEG) }\end{array}$ & $1,000(500)$ & $\begin{array}{l}\text { colour } \\
\text { histogram }\end{array}$ & $\begin{array}{l}\text { Precision }(100 \%) \\
\& \text { recall }(33.6 \%)\end{array}$ & $\begin{array}{l}\text { The } \\
\text { combined } \\
\text { automated } \\
\text { segmentatio } \\
\text { n \& region- } \\
\text { based } \\
\text { feature } \\
\text { extraction } \\
\text { algorithm } \\
\text { outperforms } \\
\text { the others } \\
\text { for CBIR }\end{array}$ \\
\hline $\begin{array}{l}\text { Wang et } \\
\text { al. }(2017)\end{array}$ & $\begin{array}{l}\text { Australia } \\
\text { (IEEE } \\
\text { Transactions } \\
\text { on Image } \\
\text { Processing) }\end{array}$ & $\begin{array}{l}\text { Landmarks } \\
\text { from Flickr } \\
\& \text { Picasa } \\
\text { Web } \\
\text { Albums } \\
(\mathrm{n} / \mathrm{a})\end{array}$ & $\begin{array}{lll}49,840 & (55) \\
\& & 4,100 \\
(16) & & \end{array}$ & $\begin{array}{l}\text { colour, } \\
\text { SIFT \& } \\
\text { CNN }\end{array}$ & $\begin{array}{l}\text { Mean average } \\
\text { precision } \\
(63.62 \%)\end{array}$ & $\begin{array}{l}\text { The novel } \\
\text { method base } \\
\text { on a multi- } \\
\text { query } \\
\text { expansion } \\
\text { paradigm } \\
\text { outperforms }\end{array}$ \\
\hline
\end{tabular}




\begin{tabular}{|c|c|c|c|c|c|c|}
\hline & & & & & & $\begin{array}{l}\text { the others } \\
\text { for CBIR }\end{array}$ \\
\hline $\begin{array}{l}\text { Hung } \\
(2018)\end{array}$ & $\begin{array}{l}\text { Taiwan } \\
\text { Electronic } \\
\text { Library) }\end{array}$ & $\begin{array}{l}\text { Chinese } \\
\text { paintings } \\
(\mathrm{n} / \mathrm{a})\end{array}$ & $1,200(3)$ & $\begin{array}{l}\text { colour } \\
\text { histogram } \\
\text { \& texture }\end{array}$ & $\begin{array}{l}\text { Mean average } \\
\text { precision }(92 \%)\end{array}$ & $\begin{array}{l}\text { The } \\
\text { combined } \\
\text { colour \& } \\
\text { texture } \\
\text { algorithm } \\
\text { performs } \\
\text { well for } \\
\text { CBIR }\end{array}$ \\
\hline $\begin{array}{l}\text { Arun et } \\
\text { al. }(2020)\end{array}$ & $\begin{array}{l}\text { India (Artificial } \\
\text { Intelligence } \\
\text { Review) }\end{array}$ & $\begin{array}{l}\text { INRIA } \\
\text { holidays } \\
\text { (JPEG), } \\
\text { Oxford } \\
\text { buildings, } \\
\text { Scene-15, } \\
\text { GHIM-10K } \\
\text { (JPEG), } \\
\text { IAPR TC- } \\
\text { 12 (JPEG) } \\
\text { \& SUN-397 }\end{array}$ & $\begin{array}{l}1,491(500), \\
5,062 \quad(11), \\
4,485 \quad(15), \\
10,000(20), \\
20,000(\mathrm{n} / \mathrm{a}) \\
\& \quad 108,754 \\
(397)\end{array}$ & SIFT & $\begin{array}{lr}\text { Mean } & \text { average } \\
\text { precision } & (83.6 \%), \\
\text { average } & \text { R- } \\
\text { Precision } & (86.7 \%) \\
\& & \text { discounted } \\
\text { cumulative } & \text { gain } \\
(89.9 \%) & \end{array}$ & $\begin{array}{l}\text { The BoVP } \\
\text { (bag of } \\
\text { visual } \\
\text { phrases) } \\
\text { algorithm } \\
\text { outperforms } \\
\text { the others } \\
\text { for CBIR }\end{array}$ \\
\hline $\begin{array}{l}\text { Basak et } \\
\text { al. }(2019)\end{array}$ & \begin{tabular}{|l|} 
India \\
(International \\
Research \\
Journal of \\
Engineering \\
and \\
Technology)
\end{tabular} & $\begin{array}{l}\text { Monuments } \\
(\mathrm{n} / \mathrm{a})\end{array}$ & $4(2)$ & shape & $\begin{array}{l}\text { Edge magnitude } \\
\text { value }\left(1.61 \text { for } 1^{\text {st }}\right. \\
\text { image \& } 1.65 \text { for } \\
\left.2^{\text {nd }} \text { image }\right)\end{array}$ & $\begin{array}{l}\text { The shape } \\
\text { feature } \\
\text { algorithm } \\
\text { performs } \\
\text { well for } \\
\text { CBIR }\end{array}$ \\
\hline
\end{tabular}

Looking at the past decade, it can be seen that the trend of CBIR study in the tourism discipline is to improve existing feature extraction techniques (47\%) to better represent image information and eventually accelerate the image retrieval performance with high efficiency and effectiveness. Nevertheless, some studies attempted to contribute novel techniques in the feature extraction process by fine-tuning fusion features $(41 \%)$ and some attempted to improve the input of CBIR system, image query $(12 \%)$.

As for the research author(s), the majority of CBIR study are collaborative works of two authors (24\%), three authors (40\%), four authors (24\%), and five authors $(6 \%)$. Only six percent of the CBIR studies are conducted by one author. Additionally, 62 percent of the studies are the collaboration between institutions, whereas 38 percent are done within an institution. Despite the fact that it is an interdisciplinary subject, all authors chose to publish their academic papers in journals/conferences in relation to STEM (science, technology, engineering, and math) subjects instead of the humanities subjects, such as leisure and tourism, social science, and business study. As for the origin country(s) of authors, Asia (65\%) is the most active continent for tourism-related CBIR studies, conducted in China (17\%), India (17\%), Iran (17\%), Taiwan (7\%), and Thailand (7\%). 
Nonetheless, scholars in Europe (17\%), Africa (12\%), and Australia (6\%) also have an interest in the topic. Furthermore, even though the CBIR studies in tourism has been published almost every year and there is a consistent number of published papers each year, more intensive study in the field could have been conducted in response to the ongoing challenges in image data management/organization in the tourism industry.

Moving to the database(s) used in each experiment. Although there are five basic elements of tourism product - attractions, accommodation, access, amenities, and activities - the tourist attraction element has been a focus of the authors, particularly in art and cultural heritage domains which are understandable as these are considered the priceless treasures of humankind from generation to generation. These databases include landmark images, monument images, historical building images, beach images, mountain images, and/or painting/object images in museums. There are fewer studies made of images in the access element (bus images), the amenities element (food images at restaurants), and the activities element (traditional/special event images). However, images of the accommodation element were not included in these studies. On top of these, many experiments used existing tourism-related databases even though not all of them contain meaningful image labels, such as INRIA holidays, Oxford buildings, and $\mathrm{ZuBuD}$ Zurich buildings, and some experiments considered other existing databases which contain tourism-related images, such as Flickr and Picasa Web Albums. Only 17 percent of the experiments created their own databases by browsing images from available search engines or taking photographs at various premises.
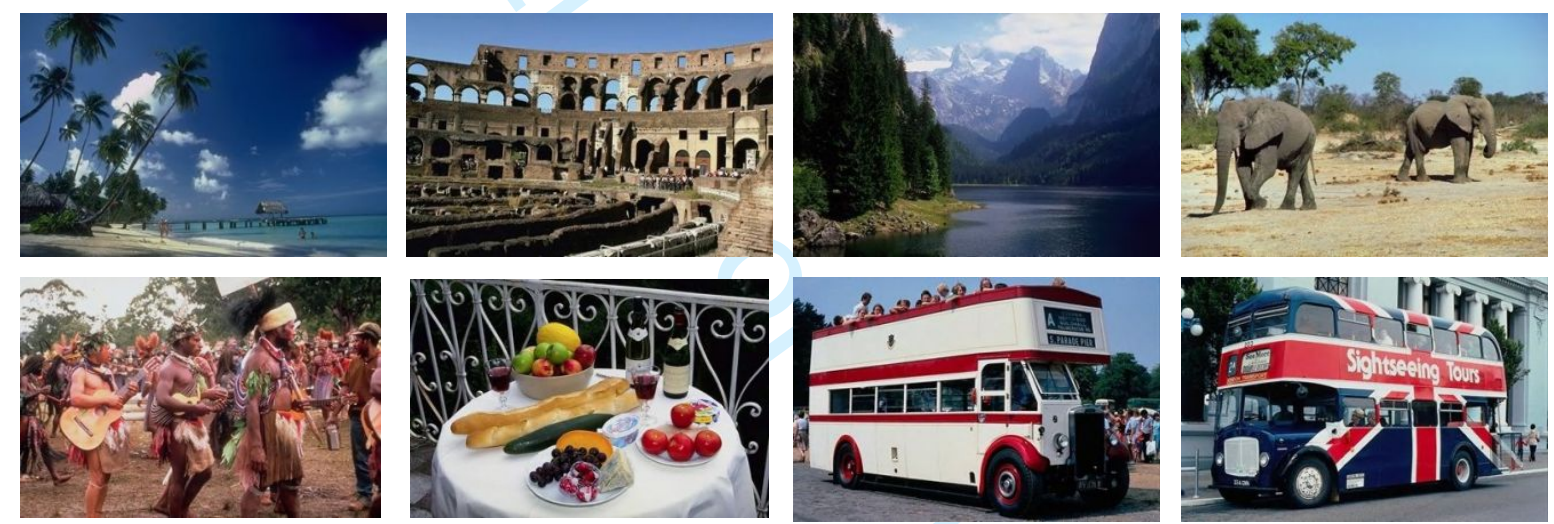

Figure 2. Image samples of the INRIA holidays database

Furthermore, it seems there is no academic scholar who has suggested a specific number for a reliable data size, or even how to calculate the appropriate data size for research in relation to image retrieval. Therefore, the choice of data size in each experiment is subjective based on the limitations of each research study, between 100 images to $1 \mathrm{M}$ images per existing database and between 1,000 images to 49,840 images per newly created database with various sizes of image category. Nevertheless, there is still a lack of images of the accommodation element in these databases and the update of the database used is not mentioned in any study which could result in dated information when applying these studies in real-life application.

In terms of image features which contain information of an image, as a part of the metadata, it can be seen the classical features were mainly extracted and the colour and/or SIFT features were the most popular choices (53\%) to represent images in the tourism context. Moreover, the approach of using a combination of features was a trend as these fusion features include significant image information on a larger scale when compared to using a single feature. Additionally, though AI-based features are the state-of-the-art which are advanced and closer to the human cognitive process, their computational complexity and cost, as well as time consumption, could be major hindrances to apply this type of feature in a small-scale study with resource and financial limitations. Having said this, there is an attempt of using CNN features to represent images.

As for the performance measurement used in CBIR studies, even though there is no single rule to evaluate the CBIR system, as it depends on the user requirement for that specific task, it is undoubted that a combination of measures, especially precision and recall, is common in these 
studies. On top of this, processing time in image classification and retrieval should not be a neglected criterion in experiments.

Considering the relevant CBIR studies above, it can be seen that there is no existing review of CBIR studies in the tourism industry has been conducted in the past decade. Therefore, this paper has filled the current research gap. On top of this, based on the results and analysis, additional research gaps have been identified for further research in the next section.

\section{Future research directions}

According to the CBIR studies in the previous section, it is undeniable that there is plenty of room to investigate and improve the organization and management of digital image data in the tourism context through CBIR. Suggestions for future directions are addressed as follow.

\subsection{CBIR for the accommodation sector}

Accommodation is one of the major parts of tourism which has an increase in number in the recent decade, particularly accommodations targeting the millennial generation have become a focus for world-dominant hoteliers, such as AccorHotels, Hilton, and Marriott (Fox, 2017; Gerrard, 2017; Mohn, 2016; Underwood, 2016). Major hostel chains, such as A\&O, Generator, Meininger, and St Christopher's Inns, have planned to expand their business while there is an increasing number of independent hostels in different parts of the world (Patrick, 2018, 2019). For this reason, the accommodation sector deserves attention from academics to facilitate the development of an efficient CBIR tool in order to manage/organize its enormous digital image collections.

\subsection{Availability of various database collections}

Due to the limitation of existing tourism-related databases aforementioned, there is a demand for more up-to-date databases of the attraction sector. Moreover, ground-truth databases of the other sectors in tourism - accommodation, access, activities, and amenities - could be made available for CBIR study in order to enhance and strengthen image data organization across all sectors in the tourism industry. Furthermore, by developing the CBIR technique for a tailored domain, image classification and retrieval tasks could contribute better performance results in response to a userspecified query for a specific problem.

\subsection{Academia and industry collaboration}

To advance CBIR study toward the AI approach, knowledge and resource exchange between academics and professionals in the industry is crucial. The academic sector could overcome financial drawbacks by gaining extra funding from the company(s), limited technology resources by using facilities of the technology company(s), and limited labour resources by sharing tasks among collaborative teams. On the industry side, the sector could benefit from a deep knowledge of the academics who tend to focus on their specialized subject(s). Moreover, the extensive commitment of the academics could assure continuity in field development which benefits the industry in the long term.

\subsection{Real-life application}

In the tourism context, only one evidence of the real-life application of CBIR is found in museum management, IBM's QBIC (query by image content) system is applied to the website of the Hermitage Museum in Russia (Jose, 2000) so people can search and appreciate the precious artworks without being at the museum. Therefore, it is obvious that more work can be done to bridge the gap between theory and real-life practice.

Despite the launch of search by image constructs by three of the key developers - Google, TinEye by Idee, and Yandex by Yandex - for the general public, as well as the launch of an AIpowered technology that uses smartphone camera and deep machine learning for object recognition and image retrieval using only visual content on mobile apps by the mobile phone giants - Bixby by Samsung, HiVision by Huawei, and Google Lens by Google - now compatible with many iOS and 
Android devices (Google, 2017; Huawei, 2018; Samsung, 2017), the organization and management of digital image databases still remains a continuous challenge, let alone the attempt to utilize CBIR for a specific domain like tourism.

\section{Conclusion}

Based on the literature review of CBIR studies in tourism using a comparative approach, it can be seen that in the past decade the research trend is to improve image representation and retrieval by advancing existing feature extraction techniques, contributing novel techniques in the feature extraction process through fine-tuning fusion features, and improving the image query of CBIR systems. The fusion of classical features, especially colour and SIFT features, remains the key tool for image representation. The limitation of available tourism-related databases which mainly focus on the tourist attraction sector is found and some of these databases show a lack of meaningful image labels. Moreover, the number of intensive studies in the field could be increased in response to the ongoing challenges in management/organization of digital image data within the tourism industry.

Lastly, this literature review has emphasized the possibility of applying the CBIR technique in digital image management for electronic libraries to overcome indexing and retrieval tasks with less labour cost and human errors, along with highlighting trends and research gaps for future research.

\section{References}

Abdullahzadeh, A. and Mohanna, F. (2013), "Content-based image retrieval based on affine noisy invariant color region", International Research Journal of Applied and Basic Sciences, Vol. 6 No. 5, pp. 598-606.

Adit, D. (2016), "The 9 deep learning papers you need to know about (understanding CNNs part 3)", available at: https://adeshpande3.github.io/The-9-Deep-Learning-Papers-You-Need-ToKnow-About.html (accessed 12 November 2019).

Alkhawlani, M., Elmogy, M. and Bakry, H. (2015), "Text-based, content-based, and semantic-based image retrievals: A survey", International Journal of Computer and Information Technology, Vol. 4 No. 1, pp. 58-66.

Amato, G., Falchi, F. and Gennaro, C. (2015), "Fast image classification for monument recognition", Journal on Computing and Cultural Heritage, Vol. 8 No. 4, Article No. 18.

Arun, K.S., Govindan, V.K. and Kumar, S.D.M. (2020), "Enhanced bag of visual words representations for content based image retrieval: A comparative study", Artificial Intelligence Review, Vol. 53, pp. 1615-1653.

Aslam, S. (2020a), "Facebook by the numbers: Stats, demographics \& fun facts", available at: www.omnicoreagency.com/facebook-statistics/ (accessed 1 May 2020).

Aslam, S. (2020b), "Instagram by the numbers: Stats, demographics \& fun facts", available at: www.omnicoreagency.com/instagram-statistics/ (accessed 1 May 2020).

Aslam, S. (2020c), "Pinterest by the numbers: Stats, demographics \& fun facts", available at: www.omnicoreagency.com/pinterest-statistics/ (accessed 1 May 2020).

Basak, P., Dhankar, P., Gupta, S. and Verma, P. (2019), "Image based information retrieval", International Research Journal of Engineering and Technology, Vol. 6 No. 5, pp. 6011-6015.

Brunel University London (2020), "Research methods in literature review", available at: https://blackboard.brunel.ac.uk/webapps/scorscormengineBBLEARN/defaultui/player/modern.html?configuration=ContentId\%7C_8413 58_1\%21CourseId\%7C_8579_1\%21CoursemembershipId\%7C_3698510_1\%21SessionId\% 7C $\%$ 21ShowDebug\%7Cfalse $\%$ 21UserId\%7C_130274_1\&preventRightClick=false\&cc $=$ en GB\&ieCompatibilityMode $=$ none\&cache $=20 \overline{1} 7.1 .13 . \overline{40}$ \& playerConfUrl $=\% 2 \mathrm{Fwebapps} \% 2$

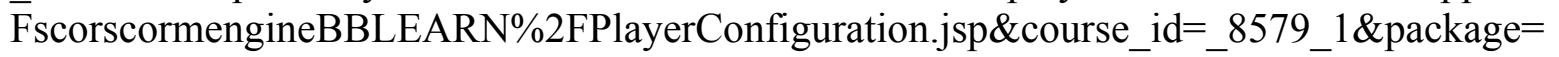
ContentId\%7C_841358_1\%21VersionId\%7C0\&registration=ContentId $\%$ 7C_ $\overline{8} 41358 \_1 \% 21$ InstanceId $\% 7 \mathrm{C0} \% 21 \mathrm{UserId} \% 7 \mathrm{C} \_130274 \_1 \&$ tracking=true \&forceReview $=\overline{\text { false } \& \text { width }}=13$ 
$66 \&$ height $=700 \&$ left $=0 \&$ top $=0 \&$ width $=1366 \&$ height $=700 \&$ left $=0 \&$ top $=0 \quad$ (accessed November 2020).

Clement, J. (2020), "Facebook access penetration 2020, by device", Statista, available at: www.statista.com/statistics/377808/distribution-of-facebook-users-by-device/ (accessed 1 May 2020).

Critical Appraisals Skills Programme (CASP) (2020), “CASP systematic review checklist", available at: https://casp-uk.net/casp-tools-checklists/ (accessed 1 June 2020).

Elleuch, Z. and Marzouki, K. (2017), "Multi-index structure based on SIFT and color features for large scale image retrieval", Multimedia Tools and Applications, Vol. 76, pp. 13929-13951.

Fox, J.T. (2017), "Targeting millennials, investors flock to hostel market", Hotel Management, available at: www.hotelmanagement.net/transactions/targeting-millennials-investors-seevalue-hostel-market (accessed 1 May 2018).

Gerrard, B. (2017), "Hostels 2.0: More than a place to sling your backpack", The Telegraph, available at: www.telegraph.co.uk/business/2017/11/27/hostels-20-place-sling-backpack/ (accessed 1 May 2018).

Google (2017), “Google lens”, available at: https://lens.google.com (accessed 1 May 2020).

Huawei (2018), "What is HiVision?", available

at: https://consumer.huawei.com/uk/support/faq/what-is-hivision/ (accessed 1 May 2020).

Hung, C, (2018), "A study on a content-based image retrieval technique for Chinese paintings", The Electronic Library, Vol. 36 No. 1, pp. 172-188.

Jose, S. (2000), "QBIC enables remote museum tours", available at: www.almaden.ibm.com/almaden/hermitage.html (accessed 1 May 2018).

Kruthika, K.R., Rajeswari, and Maheshappa, H.D. (2019), "CBIR system using capsule networks and 3D CNN for Alzheimer's disease diagnosis”, Informatic in Medicine Unlocked, Vol. 14 No. 1, pp. 59-68.

Lacheheb, H. and Aouat, S. (2017), "SIMIR: New mean SIFT color multi-clustering image retrieval", Multimedia Tools and Applications, Vol. 76, pp. 6333-6354.

Lonarkar, V. and Roa, B.A. (2017), "Content-based image retrieval by segmentation and clustering”, in International Conference on Inventive Computing and Informatics (ICICI '17), IEEE, pp. 771-776.

Makantasis, K., Doulamis, A., Doulamis, N. and Ioannides, M. (2016), "In the wild image retrieval and clustering for 3D cultural heritage landmarks reconstruction", Multimedia Tools and Applications, Vol. 75, pp. 3593-3629.

Mill, R. and Morrison, A. (1985), The Tourism System: An Introductory Text, Prentice-Hall, Englewood Cliffs, NJ.

Mohn, T. (2016), "Hostels are more popular than ever among travel-learning millennials", Forbes, available at: www.forbes.com/sites/tanyamohn/2016/05/16/a-hostel-revolution-fueled-byyoung-travelers/\#5ee7ae1c6bb4 (accessed 1 May 2018).

Muller, H., Michoux, N., Bandon, D. and Geissbuhler, A. (2003), “A review of content-based image retrieval systems in medical applications-clinical benefits and future directions", International Journal of Medical Informatics, Vol. 73 No. 1, pp. 1-23.

Murphy, P.E., Pritchard, M.P. and Smith, B. (2000), "The destination product and its impact on traveler perceptions", Tourism Management, Vol. 21 No. 1, pp. 43-52.

Patrick, W. (2018), "The big-money reinvention of the humble hostel: A Skift deep dive", Skift, available at: https://skift.com/2018/11/12/the-big-money-reinvention-of-the-humble-hostela-skift-deep-dive/ (accessed 2 October 2019).

Patrick, W. (2019), "Meet the Ryanair of the hostel industry", Skift, available at: https://skift.com/2019/04/11/meet-the-ryanair-of-the-hostel-industry/ (accessed 2 October 2019).

Premchaiswadi, W., Tungkatsathan, A. and Premchaiswadi, N. (2010), "Mobile image search for tourist information using ACCC algorithm", in 21st Annual IEEE International Symposium on Personal, Indoor and Mobile Radio Communications, IEEE, pp. 2557-2562. 
Raisi, Z., Mohanna, F. and Rezaei, M. (2014), “Applying content-based image retrieval techniques to provide new services for tourism industry", International Journal Advanced Networking and Applications, Vol. 6 No. 2, pp. 2222-2232.

Raisi, Z., Mohanna, F. and Rezaei, M. (2011), "Content-based image retrieval for tourism application", in 7th Iranian Conference on Machine Vision and Image Processing, IEEE, pp. $1-5$.

Sabharwal, A. (2017), "500 million people using Google photos, and three new ways to share", available at: https://blog.google/products/photos/google-photos-500-million-new-sharing/ (accessed 1 May 2020).

Samsung (2017), "Bixby", available at: www.samsung.com/global/galaxy/apps/bixby/vision/ (accessed 1 May 2020).

Santini, S. and Jain, R.C. (1997), "The graphical specification of similarity queries", Journal of Visual Languages and Computing, Vol. 7 No. 1, pp. 403-421.

Smith, S.L.J. (1994), "The tourism product", Annuals of Tourism Research, Vol. 21 No. 3, pp. 582595.

Stadlen, A. (2019), "Update on creative commons licenses and 'in memoriam' accounts", available at: $\quad$ https://blog.flickr.net/2019/03/08/update-on-creative-commons-licenses-and-inmemoriam-accounts/ (accessed 1 May 2020).

Tzelepi, M. and Tefas, A. (2017), "Deep convolutional learning for content-based image retrieval”, Neurocomputing, Vol. 275, pp. 2467-2478.

Underwood, B. (2016), "Why millennials (and investors) are flocking to US hostels", Forbes, available at: www.forbes.com/sites/under30network/2016/07/14/why-millennials-andinvestors-are-flocking-to-u-s-hostels/\#4ad8c60a534f (accessed 1 May 2019).

Wang, Y., Lin, X., Wu, L. and Zhang, W. (2017), "Effective multi-query expansions: Collaborative deep networks for robust landmark retrieval", IEEE Transactions on Image Processing, Vol. 26 No. 3, pp. 1393-1404.

Wang, Y., Lin, X., Wu, L. and Zhang, W. (2015), "Effective multi-query expansions: Robust landmark retrieval", in Proceedings of the 23rd ACM International Conference on Multimedia (MM'15), pp. 79-88.

Wengert, C., Douze, M. and Jégou, H. (2011), "Bag-of-colours for improved image search", Proceedings of the 19th ACM International Conference on Multimedia (MM '11), pp. 14371440.

World Travel \& Tourism Council (WTTC) (2020), "Economic impact reports", available at: https://wttc.org/Research/Economic-Impact (accessed 1 June 2020).

Zheng, L., Wang, S. and Tian, Q. (2014), "Coupled binary embedding for large-scale image retrieval”, IEEE Transactions on Image Processing, Vol. 23 No. 8, pp. 3368-3380.

Zhou, W., Li, H. and Tian, Q. (2017), "Recent advance in content-based image retrieval: A literature survey", available at: https://arxiv.org/abs/1706.06064 (accessed 12 November 2019).

Zhu, L., Shen, J., Jin, H., Zheng, R. and Xie, L. (2015), “Content-based visual landmark search via multimodal hypergraph learning”, IEEE Transactions on Cybernetics, Vol. 45 No. 12, pp. 2756-2769. 